\title{
Shading and slow release fertiliser affect early growth in seedlings of Pau-marfim
}

\author{
Oscar José Smiderle ${ }^{1}$ (i) \\ Aline das Graças Souza ${ }^{2,3}$ \\ Renata Diane Menegatti ${ }^{4}$ \\ Thiago Jardelino Dias ${ }^{5}$ (1) \\ Raiovane Araújo Montenegro 6 (1)
}

\begin{abstract}
The aim of this study was to evaluate the initial growth of Agonandra brasiliensis Miers ex Benth. \& Hook. F. in response to different levels of shading and doses of controlled-release fertiliser (CRF). The experiment was conducted at Embrapa Roraima in Boa Vista, in a completely randomised experimental design and a $2 \times 5$ factorial scheme, of two luminosity levels (50 and 30\%) and five doses of CRF (formulation 18-05-09, NPK) $(0,0.5,1,2$ and $3 \mathrm{~g} \mathrm{~L}^{-1}$ substrate), with five replications, each consisting of five plants. At 240 days after transplanting, the growth characteristics were evaluated, and the influence of the light levels and the CRF dose was recorded on these characteristics, either individually or interactively. It is suggested that plants of Agonandra brasiliensis be fertilised with a dose of $2 \mathrm{~g} \mathrm{~L}^{-1} \mathrm{CRF}$ and grown in an environment with $50 \%$ of luminosity to maximize growth and efficiency in the production of high-quality seedlings.
\end{abstract}

Keywords: Ambiance, Native forest species, Plant nutrition, Seedling production.

\section{INTRODUCTION}

The production of knowledge guiding optimal measures of fertilisation is essential in the production of seedlings of native forest species of superior commercial characteristics, and which can enhance success when planting forest stands for the purposes of timber, and also guarantee their establishment and survival in programs for the recovery of degraded areas, since their growth and development would be governed by information basic to the balanced management of nutrients that maximise growth (Schott et al., 2016).

This is because the application of fertiliser in suitable proportions, when adjusted for a given species, affords the ideal amount of essential nutrients to the compounds and molecules related to photosynthetic metabolism, promoting the maintenance of assimilation rates that guarantee superior growth characteristics, such as robustness and dry matter production (Epstein and Bloom, 2006), both sought after by the forestry sector (CNI, 2017).

The species, Agonandra brasiliensis Miers ex Benth. \& Hook. F., popularly known as pau-marfim, has been the subject of recent research due to its economic potential (providing noble wood for various uses), and environmental possibilities, since it produces fruits that are attractive to fauna in general (Ramalho \& Zappi, 2017, Cysneiros et al., 2018, Moraes et al., 2018, Souza et al., 2020). Its multiple uses make it attractive, but because it is a climax species (adapted to shade) (Gualberto et al., 2014), it grows slowly and

${ }^{1}$ Empresa Brasileira de Pesquisa Agropecuária, Boa Vista, RR, Brasil

${ }^{2}$ Universidade Federal da Paraíba, Departamento de Agricultura, Areia, PB, Brasil

${ }^{3}$ Universidade Federal de Pelotas, Campus Capão do Leão, Pelotas, RS, Brasil

${ }^{4}$ Universidade do Estado de Santa Catarina, Ciências Agrárias, Lages, SC, Brasil

${ }^{5}$ Universidade Federal da Paraíba, Departamento de Agricultura, Bananeiras, PB, Brasil

${ }^{6}$ Universidade Federal de Roraima, Boa Vista, RR, Brasil 
after planting, any guarantee of survival and resilience under the new conditions is directly related to the nutritional status of the seedlings (Ramalho \& Zappi, 2017).

The nutritional management of plants in a greenhouse, when carried out, includes the use of conventional fertilisers, as a rule, employing the same source used after planting, in random formulations and doses which have not been previously evaluated as to their efficiency for the growth and performance of the species (Ao et al., 2018). In addition, this source of nutrients is readily soluble and once management is carried out, the elements are immediately available to the plants, resulting in effects that are direct and rapid, albeit causing losses through leaching, a factor that maximizes costs and increases environmental damage (Azeem et al., 2014, Wang et al., 2016).

As an alternative, the use of controlled-release fertilisers (CRF) has been described as an effective tool for fertilising the seedlings of forest species in the nursery, as it induces rapid initial growth and promotes survival after planting in the field (Fu et al., 2017, Menegatti et al., 2017, Ao et al., 2018, Araújo et al., 2019). However, studies that consider a specific species and its peculiarities are necessary, as these would allow a rational and efficient use of nutrients by the plant, thereby avoiding waste (Shi et al., 2019).

Souza et al. (2020) suggest the addition of CRF (18-05-09, NPK) when a substrate of medium sand is to be used in the production of Agonandra brasiliensis seedlings, as this makes it possible to obtain more-robust plants, with balanced biomass distribution and a high standard of quality. Guo et al. (2016) showed that CRF (composed of NPK) has a positive effect on growth in Ginkgo biloba, maximising this effect when specific doses are applied that have been determined to allow balanced nutrition with robust plants and commercial characteristics of interest, i.e. a larger root collar diameter and a well-developed root system. Asante et al. (2017) obtained superior plants when using CRF, with an obvious improvement in nutrient uptake and dry matter partitioning in Xanthosoma sagittifolium L. furthermore, these effects were maximized when the lighting conditions in the greenhouse were also considered.

Among the factors that affect seedling production, one of the most important is the environment; the use of protected environments and/or shade screens allows the irradiance to be controlled, and consequently affects the relative humidity and availability of water in the production area, variables that are managed with a view to greater plant growth (Arantes et al., 2019, Araújo et al., 2019). The ambiance provides control of irradiance through manipulation of the growing environment, allowing temperature, humidity and light to be kept at suitable levels for maintaining satisfactory photosynthetic rates, which, if achieved, can result in better dry matter accumulation, as well as more adequate distribution of matter among the plant organs (Pan et al., 2016), attributes described as being closely related to post-planting growth (Grossnickle \& MacDonald, 2018).

The effects of adding controlled-release fertiliser to different substrates indicated for the production of paumarfim seedlings, have already been described (Souza et al., 2020), however, there have been no studies involving the effects of shading together with the use of this nutrient source. The aim of this work, therefore, was to evaluate the initial growth of seedlings of Agonandra brasiliensis Miers ex Benth. \& Hook. F. in response to different levels of shading and doses of controlled-release fertiliser.

\section{MATERIALS AND METHODS}

Seeds of Agonandra brasiliensis, were collected from trees located in the district of Boa Vista, in the state of Roraima. The experiment was conducted from September 2018 to June 2019 at the seed analysis laboratory and seedling nursery of the forestry sector of Embrapa Roraima, at $2^{\circ} 45^{\prime} 22^{\prime \prime} \mathrm{N}$ and $60^{\circ} 43^{\prime} 55 \mathrm{~W}$, and an average altitude of 80 metres.

After obtaining the seeds, they were processed and then sown in a bed containing washed medium sand as substrate for the germination and initial development of the seedlings. The moisture in the substrate was maintained by manual irrigation four times a day.

Approximately 30 days after sowing, the process of seedling emergence began; once the seeds had all reached an approximate height of $12.0 \mathrm{~cm}$, they were transplanted into polyethylene bags $(15 \times 35 \mathrm{~cm})$ containing a substrate of washed medium sand (Table 1) into which, based on each treatment, doses of encapsulated controlled-release fertiliser (Forth Cote ${ }^{\circ}$ ) in NPK 18-05-09 formulation were incorporated into the surface.

Table 1. Chemical composition of the washed medium sand used in the production of seedlings of Agonandra brasiliensis seedlings.

\begin{tabular}{|c|c|c|c|c|c|c|c|c|c|c|c|c|c|}
\hline Substrate & $\mathbf{O M}$ & V & Al & $\mathbf{H}+\mathbf{A l}$ & SB & CEC & $\mathbf{P}$ & K & $\mathrm{Ca}$ & $\mathrm{Mg}$ & $\mathrm{Zn}$ & $\mathrm{Fe}$ & Mn \\
\hline & \multicolumn{2}{|c|}{$\%$} & \multicolumn{4}{|c|}{$\mathrm{cmol}_{\mathrm{c}} \mathrm{dm}^{-3}$} & \multicolumn{4}{|c|}{$\mathrm{mg} \mathrm{dm} \mathrm{m}^{-3}$} & \multicolumn{3}{|c|}{$\mu \mathrm{g} \mathrm{dm}^{-3}$} \\
\hline Sand & 0.00 & 67.00 & 0.00 & 0.00 & 0.00 & 0.00 & 0.00 & 0.00 & 0.00 & 0.00 & 0.44 & 0.00 & 0.00 \\
\hline
\end{tabular}

OM: Organic Matter; V: Base saturation; SB: Sum of Bases; CEC: Cation Exchange Capacity (CEC). 
The plants were then placed in a screened nursery under $50 \%$ and $30 \%$ of luminosity (Figure 1), with sprinkler irrigation programmed every six hours during the day; each irrigation lasted for five minutes.

The illuminance afforded by the different coverings was determined by sampling, with measurements taken during the first three days of each month at six different times during the day $(800,1000,1200,1400,1600$ and 1800). To characterise the transparency provided by the different coverings, the average of the evaluations up to 240 days after transplanting the seedlings was used. The mean temperature during the experimental period was $25 \pm 5^{\circ} \mathrm{C}$ with a relative humidity of from $60 \%$ to $70 \%$.

The experimental design was completely randomised in a $2 \times 5$ factorial scheme, with two luminosity levels (50\% and $30 \%$ ) and five doses of Forth Cote ${ }^{\circ}$ controlled-release fertiliser $\left(0,0.5,1,2\right.$ and $3 \mathrm{~g} \mathrm{~L}^{-1}$ of substrate), with five replications, each consisting of five seedlings (one in each container).

At 240 days after transplanting (DAT), the plants were evaluated for shoot length $(\mathrm{H})$, with the aid of a graduated rule, and collar diameter (CD) with a digital calliper.
The plants were then dried in a forced air circulation oven at $70^{\circ} \mathrm{C}$ for 72 hours to constant weight, for individual determination of the shoot dry matter (SDM, g plant $\left.{ }^{-1}\right)$, root dry matter (RDM, g plant ${ }^{-1}$ ) and total dry matter (TDM, g plant $\left.{ }^{-1}\right)$, the latter obtained from the sum of the two variables $(\mathrm{SDM}+\mathrm{RDM})$. The Dickson quality index was determined using the formula DQI $=\mathrm{TDM} /[(\mathrm{H} / \mathrm{CD})+(\mathrm{SDM} / \mathrm{RDM})]$. The shoot dry matter to root dry matter ratio (RSDM/ $\mathrm{RDM})$ and root dry matter (RDM) were determined from the variables resulting from the material dried in the oven.

The increase in height $(\mathrm{IncH})$ and collar diameter ( $\mathrm{IncCD})$ was obtained from data collected every thirty days during the period of plant growth until the end of the experiment (240 days).

Possible differences between treatments were verified by analysis of variance of the data (ANOVA). The mean value of each variable was compared by Tukey's test at $5 \%$ probability, with the quantitative variables submitted to regression analysis in order to verify the growth response of the plants as a function of time. The data analysis was carried out using the Sisvar statistical software (Ferreira, 2014).

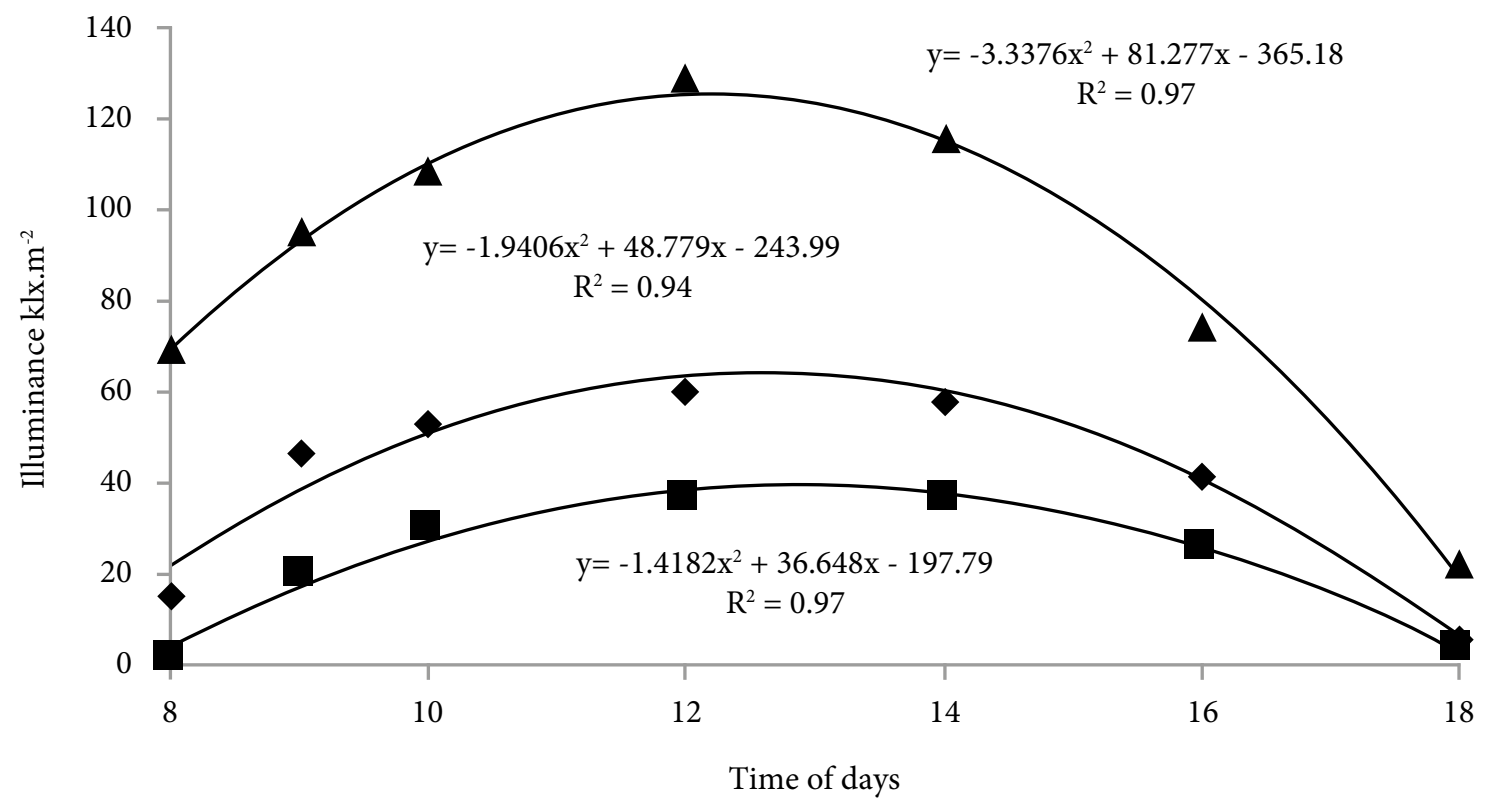

$\checkmark$ Illuminance $50 \% \quad \boldsymbol{\Delta}$ Olluminance $30 \%$ Open air

Figure 1. Illuminance recorded in the environments (luminosity levels and open air) over the entire production period, for seedlings of Agonandra brasiliensis.

\section{RESULTS}

The analysis of variance revealed a significant effect $(p<0.01)$ for the interaction between the factors luminosity (L) and dose of controlled-release fertiliser (D) for the variables height, shoot dry weight, shoot dry weight to root dry weight ratio, and increase in height (Table 2), suggesting that the application of different combinations of $\mathrm{L}$ and $\mathrm{D}$ may have a direct influence on plant growth, as well as on biomass accumulation. It should be noted that the significant 
individual effect of factor $\mathrm{D}$ was obtained in each variable under consideration; while for the individual effect of factor $\mathrm{L}$, significant differences were found in the variables related to dry matter (SDM, RDM, TDM, RSDM/RDM and DQI), and also for the increase in height $(\mathrm{IncH})$.

Greater mean values for height, shoot dry matter, shoot to root dry matter ratio, and increase in height were recorded in plants fertilised with $2 \mathrm{~g} \mathrm{~L}^{-1} \mathrm{CRF}$ in an environment with 50\% luminosity (Table 3); however, these mean values, despite being significantly greater, were not considered statistically different from those obtained with the use of both smaller and higher doses of fertiliser, when the plants were grown in a less bright environment (30\%), suggesting that luminosity acts as a determining factor in the superiority of these growth characteristics in plants of Agonandra brasiliensis, in contrast to the fertiliser.

The greatest mean value for height recorded in the plants of Agonandra brasiliensis was $40.6 \mathrm{~cm}$ when grown with $2 \mathrm{~g} \mathrm{~L}^{-1} \mathrm{CRF}$ in an environment with $50 \%$ of luminosity, showing a reduction of approximately $37 \%$ for the two best treatments in relation to plants grown under reduced light (30\%), with values of 25.6 and $24.8 \mathrm{~cm}$ when grown with 1 and $3 \mathrm{~g} \mathrm{~L}^{-1} \mathrm{CRF}$, respectively. Similar behaviour was seen for the increase in height, with the highest mean value $(22.5 \mathrm{~cm})$ recorded in plants of Agonandra brasiliensis grown with $2 \mathrm{~g}$ $\mathrm{L}^{-1} \mathrm{CRF}$ in an environment with $50 \%$ of luminosity, followed by a reduction of $43.2 \%$ recorded for the best treatment in an environment with $30 \%$ of luminosity, $3 \mathrm{~g} \mathrm{~L}^{-1} \mathrm{CRF}$.

The results obtained for shoot dry matter were similar to those registered for the shoot to root dry matter ratio; the highest mean value for these variables was $4.06 \mathrm{~g} \mathrm{plant}^{-1}$ and 0.54 respectively, obtained in plants of Agonandra brasiliensis grown with $2 \mathrm{~g} \mathrm{~L}^{-1} \mathrm{CRF}$ in an environment with $50 \%$ of luminosity, followed by the treatment whose plants were fertilised with $1 \mathrm{~g} \mathrm{~L}^{-1} \mathrm{CRF}$ under $30 \%$ of luminosity.

It is worth noting that the absence of CRF, as well as the lowest dose under test $\left(0.5 \mathrm{~g} \mathrm{~L}^{-1}\right)$, resulted in inferior values for these variables regardless of the light level, i.e. the growth environment.

Table 2. Summary of the analysis of variance for the growth variables collar diameter (CD), height (H), shoot dry matter (SDM), root dry matter (RDM), total dry matter (TDM), shoot to root dry matter ratio (RSDM/RDM), Dickson quality index (DQI), increase in collar diameter (IncCD) and increase in height (IncH), as a function of the luminosity level and dose of controlled-release fertiliser, in seedlings of Agonandra brasiliensis grown in a greenhouse.

\begin{tabular}{|c|c|c|c|c|c|c|c|c|c|c|}
\hline \multirow[b]{2}{*}{ Variation Source } & & \multicolumn{9}{|c|}{ Mean Square } \\
\hline & DF & $\begin{array}{c}\mathrm{CD} \\
(\mathrm{mm})\end{array}$ & $\begin{array}{c}\mathrm{H} \\
(\mathrm{cm})\end{array}$ & $\begin{array}{c}\text { SDM } \\
\left(\text { g plant }^{-1}\right)\end{array}$ & $\begin{array}{c}\text { RDM } \\
\left(\text { g plant }^{-1}\right)\end{array}$ & $\begin{array}{c}\text { TDM } \\
\left(\text { g plant }^{-1}\right)\end{array}$ & $\begin{array}{c}\text { RSDM } \\
\text { RDM }\end{array}$ & DQI & $\begin{array}{l}\text { D Inc } \\
(\mathrm{mm})\end{array}$ & $\begin{array}{c}\text { H Inc } \\
(\mathrm{cm})\end{array}$ \\
\hline Luminosity (L) & 1 & $0.56^{\mathrm{ns}}$ & $62.72^{\mathrm{ns}}$ & $9.16^{* *}$ & $10.21^{* *}$ & $38.54^{* *}$ & $0.14^{* *}$ & $0.40^{* *}$ & $1.22^{\mathrm{ns}}$ & $0.17^{* *}$ \\
\hline Dose (D) & 4 & $6.37^{* *}$ & $195.63^{* *}$ & $6.49^{* *}$ & $20.89^{* *}$ & $50.44^{* *}$ & $0.03^{* *}$ & $0.66^{* *}$ & $1.40^{* *}$ & $207.51^{*}$ \\
\hline L x D & 4 & $0.71^{\mathrm{ns}}$ & $208.17^{* *}$ & $1.48^{* *}$ & $2.58^{\mathrm{ns}}$ & $7.91^{\mathrm{ns}}$ & $0.015^{* *}$ & $0.004^{\mathrm{ns}}$ & $0.46^{\mathrm{ns}}$ & $167.26^{*}$ \\
\hline Residual & 40 & 0.22 & 50.28 & 0.35 & 0.92 & 2.35 & 0.02 & 0.05 & 0.17 & 37.80 \\
\hline Mean & & 3.72 & 25.76 & 1.88 & 4.08 & 5.96 & 0.44 & 0.82 & 1.43 & 10.22 \\
\hline CV (\%) & & 12.58 & 27.53 & 31.55 & 23.58 & 25.74 & 11.23 & 28.2 & 29.14 & 60.15 \\
\hline
\end{tabular}

** and ns: significant and not significant, respectively, at $1 \%$ of probability.

Table 3. Mean values for the interaction between luminosity and doses of controlled-release fertiliser for the growth variables height $(\mathrm{H})$, shoot dry matter (SDM), shoot to root dry matter ratio (RSDM/RDM), and increase in height (IncH), in seedlings of Agonandra brasiliensis grown in a greenhouse.

\begin{tabular}{|c|c|c|c|c|c|}
\hline \multirow{3}{*}{ Luminosity (L) } & \multicolumn{5}{|c|}{ Dose $\left(\mathrm{g} \mathrm{L}^{-1}\right)$} \\
\hline & \multicolumn{5}{|c|}{$\mathrm{H}(\mathbf{c m})$} \\
\hline & 0 & 0.5 & 1 & 2 & 3 \\
\hline $50 \%$ & $19.20 \mathrm{aB}$ & $20.00 \mathrm{aB}$ & $24.2 \mathrm{aB}$ & $40.60 \mathrm{aA}$ & $30.40 \mathrm{aAB}$ \\
\hline $30 \%$ & $22.60 \mathrm{aB}$ & $22.40 \mathrm{aB}$ & $24.8 \mathrm{aA}$ & $23.8 \mathrm{bB}$ & $25.60 \mathrm{aA}$ \\
\hline \multicolumn{6}{|c|}{ SDM (g plant $\left.{ }^{-1}\right)$} \\
\hline $50 \%$ & $1.24 \mathrm{aC}$ & $1.50 \mathrm{aC}$ & $2.00 \mathrm{aBC}$ & $4.06 \mathrm{aA}$ & $2.76 \mathrm{aB}$ \\
\hline $30 \%$ & $0.54 \mathrm{bB}$ & $1.40 \mathrm{aAB}$ & $1.64 \mathrm{aA}$ & $1.98 \mathrm{bA}$ & $1.72 \mathrm{bA}$ \\
\hline \multicolumn{6}{|c|}{ RSDM/RDM } \\
\hline $50 \%$ & $0.45 \mathrm{aB}$ & $0.46 \mathrm{aB}$ & $0.48 \mathrm{aB}$ & $0.54 \mathrm{aA}$ & $0.48 \mathrm{aB}$ \\
\hline $30 \%$ & $0.24 \mathrm{bC}$ & $0.44 \mathrm{aAB}$ & $0.47 \mathrm{aA}$ & $0.41 \mathrm{bBC}$ & $0.38 \mathrm{bB}$ \\
\hline \multicolumn{6}{|c|}{ H Inc (cm) } \\
\hline $50 \%$ & $2.26 \mathrm{aC}$ & $4.20 \mathrm{aCB}$ & $7.26 \mathrm{bCB}$ & $22.5 \mathrm{aA}$ & $14.60 \mathrm{aAB}$ \\
\hline $30 \%$ & $2.20 \mathrm{aC}$ & $4.20 \mathrm{aB}$ & $12.00 \mathrm{aA}$ & $9.00 \mathrm{bB}$ & $13.00 \mathrm{aA}$ \\
\hline
\end{tabular}

${ }^{1}$ Lowercase letters ( $\mathrm{a}, \mathrm{b}$ and $\mathrm{c}$ ) compare mean values for the variables within each dose of fertiliser between luminosity levels. Uppercase letters (A, B and C) compare mean values for the variables within each luminosity level between doses of fertiliser, by Tukey's test at $1 \%$ probability. 
For the variables that showed an individual significant effect for factor $\mathrm{D}$, the greatest mean value for collar diameter was $4.26 \mathrm{~mm}$, seen in plants fertilised with $2 \mathrm{~g} \mathrm{~L}^{-1} \mathrm{CRF}$, with a reduction of $7.7 \%$ in the treatment where the plants were grown at the highest dose $\left(3 \mathrm{~g} \mathrm{~L}^{-1} \mathrm{CRF}\right)$; this value, however, was not considered statistically different (Figure 2A). Similar behaviour was recorded for the increase in collar diameter (Figure 2B), with the highest value of $1.95 \mathrm{~mm}$ seen in plants fertilised with $2 \mathrm{~g} \mathrm{~L}^{-1} \mathrm{CRF}$, and a reduction of $17.2 \%$ for the treatment at the highest dose $\left(3 \mathrm{~g} \mathrm{~L}^{-1} \mathrm{CRF}\right)$, which was also not considered statistically different from the best result.

Similar to the $\mathrm{CD}$, the highest mean values obtained for root dry matter (RDM), total dry matter (TDM) (Figure 3A and $B$ ) and the Dickson quality index (DQI) (Figure 4) were in plants of Agonandra brasiliensis fertilised with $2 \mathrm{~g} \mathrm{~L}^{-1} \mathrm{CRF}$. The first two variables were also not considered statistically different from the best result obtained at the higher dose ( $3 \mathrm{~g} \mathrm{~L}^{-1} \mathrm{CRF}$ ). It is important to note that the Dickson quality index in plants grown at the dose of $2 \mathrm{~g} \mathrm{~L}^{-1}$ was 1.28 , which is the only value for this parameter greater than 1 , considering all the treatments under test.

It should be noted that all the variables that showed an individual statistical difference for D (Figures 2, 3 and 4) displayed the lowest values in treatments that included either the absence of CRF or the lowest dose under test $\left(0.5 \mathrm{~g} \mathrm{~L}^{-1}\right)$, suggesting that fertilisation based on the requirements of Agonandra brasiliensis is indispensable in the initial growth stage of the seedlings.

The variables that showed an individual significant effect for L, root dry matter, total dry matter and the Dickson quality index, generally had higher values in plants of Agonandra brasiliensis grown in an environment with $50 \%$ of luminosity, i.e. when subjected to greater light intensity, as can be seen in Table 4. The reduction in root dry matter and total dry matter was approximately 34 and $29 \%$ respectively between the treatments with 50 and $30 \%$ of luminosity.
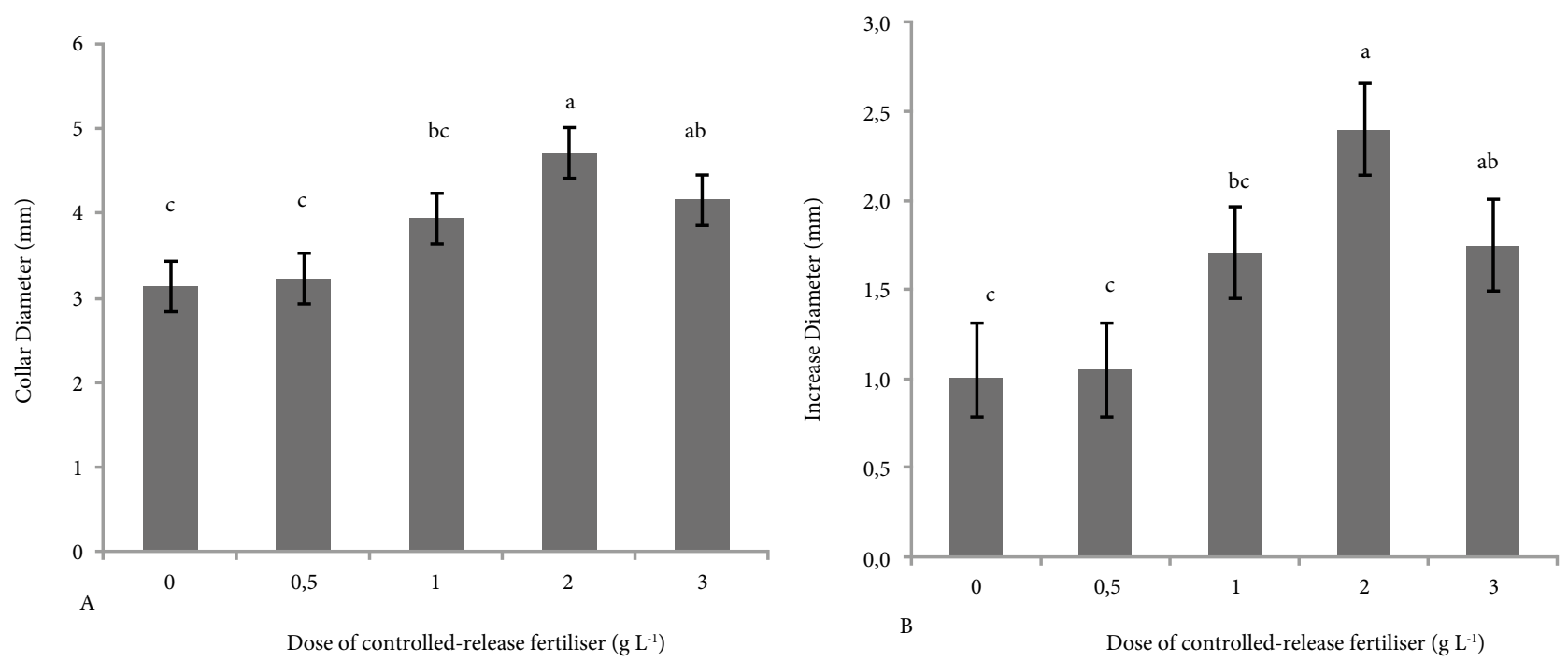

Figure 2. Mean value for collar diameter (A) and increase in collar diameter (B) as a function of shading and doses of controlled-release fertiliser, in seedlings of Agonandra brasiliensis grown in a greenhouse. ${ }^{1}$ Lowercase letters $(\mathrm{a}, \mathrm{b}$ and $\mathrm{c})$ compare the means for the variable between the doses of controlled-release fertiliser. 

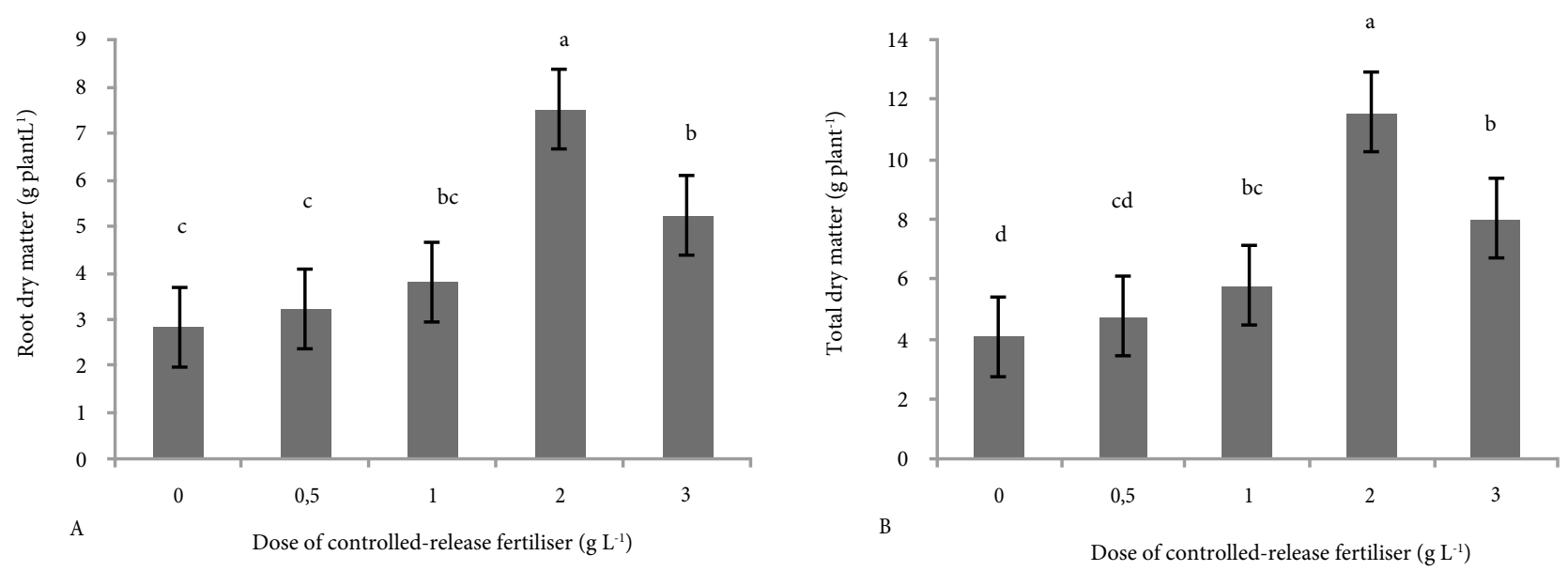

Figure 3. Mean value for root dry matter (A) and total dry matter (B), as a function of shading and doses of controlled-release fertiliser, in seedlings of Agonandra brasiliensis grown in a greenhouse. ${ }^{1}$ Lowercase letters ( $\mathrm{a}, \mathrm{b}, \mathrm{c}$ and $\mathrm{d}$ ) compare the mean values for the variable between the doses of controlled-release fertiliser.

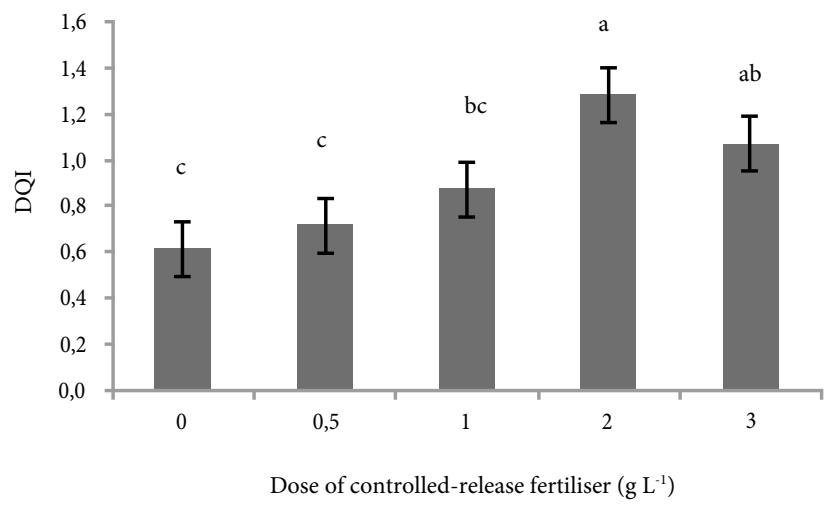

Figure 4. Mean value for the Dickson quality index (DQI), as a function of shading and doses of controlled-release fertiliser, in seedlings of Agonandra brasiliensis grown in a greenhouse. ${ }^{1}$ Lowercase letters ( $\mathrm{a}, \mathrm{b}$ and $\mathrm{c}$ ) compare the means for the variable between the doses of controlled-release fertiliser.

Table 4. Mean values for the root dry matter (RDM), total dry matter (TDM) and Dickson quality index (DQI), as a function of luminosity level, in seedlings of Agonandra brasiliensis grown in a greenhouse.

Luminosity (L) RDM ( g plant $\left.^{-1}\right) \quad$ TDM ( g plant $\left.^{-1}\right) \quad$ DQI

\begin{tabular}{llll}
$50 \%$ & $4.53 \mathrm{a}$ & $6.83 \mathrm{a}$ & $0.91 \mathrm{a}$ \\
$30 \%$ & $3.62 \mathrm{~b}$ & $5.08 \mathrm{~b}$ & $0.73 \mathrm{~b}$ \\
\hline
\end{tabular}

${ }^{1}$ Lowercase letters ( $a$ and $b$ ) compare the mean values for the variables within each luminosity level, by Tukey's test at $1 \%$ of probability.

\section{DISCUSSION}

According to some researchers, enrichment of the substrate with CRF allows the best use of this input by the plants, since the gradual release of the fertiliser enables nutrients to be recovered efficiently, explaining the greater height, as well as maximised shoot dry matter production recorded in seedlings of several forest species, including Canafistula (Peltophorum dubium) (Spreng.) Taubert, Guatambu (Aspidosperma parvifolium) A. SD. and Araticum (Anonna cacans) Warm. (Dutra et al., 2016, Menegatti et al., 2017, Smiderle et al., 2020).

The slow release and the absorption of the ideal amount of nutrients throughout the growth period of the seedlings seems to favour the formation and activation of the compounds and processes related to photosynthesis, thereby inducing greater efficiency in the physiological processes that promote rapid initial growth in plants (Fu et al., 2017, Ao et al., 2018, Araújo et al., 2019, Menegatti et al., 2019).

The greater height and shoot dry matter in seedlings grown with $2 \mathrm{~g} \mathrm{~L}^{-1}$ in an environment with more light may be related to the combined action of these two factors, i.e. the availability of nutrients at an appropriate dose for the species and the stage of plant development, together with exposure to a luminosity level of $50 \%$. The latter probably resulted in the absorption of light energy in sufficient quantity to maintain a high rate of photosynthesis, which in turn resulted in an increase in dry matter accumulation in the shoots, as well as an increase in height (Araújo et al., 2019).

Souza et al. (2020), testing the growth of seedlings of Agonandra brasiliensis with and without the application of $1 \mathrm{~g} \mathrm{~L}^{-1} \mathrm{CRF}$ (NPK 18-05-09), suggests adding this fertiliser to the sand substrate when producing seedlings, as this makes it possible to obtain more-robust plants with balanced biomass distribution and a high standard of quality. However, the results obtained with different doses of this fertiliser in the above study, show that using a dose of $2 \mathrm{~g} \mathrm{~L}^{-1}$, and no more, 
can maximize plant growth, when taking into account the interaction of input with light level, i.e. management of the environment.

Asante et al. (2017) obtained plants with better growth characteristics when using CRF, with obvious improvement in nutrient uptake and dry matter partitioning in Xanthosoma sagittifolium L., with these effects maximised when the lighting in the greenhouse was also considered. Similarly, greater height was reported by Araújo et al. (2019) in seedlings of Euterpe oleracea when grown under $50 \%$ of luminosity, compared to the lower light levels they tested (20 and $30 \%$ of luminosity).

Despite Agonandra brasiliensis being characterised as a climax species (adapted to shade) (Gualberto et al., 2014) as stated above, the results show that at the beginning of the plant growth phase, light is essential for promoting the emission and maintenance of new leaves, maximizing efficiency in the capture of solar energy, and consequently in the photosynthetic assimilation of carbon, which culminate in an increase in height and the accumulation of dry matter, suggesting that metabolic processes in Agonandra brasiliensis may benefit from a greater amount of light during this period of growth.

The individual effects of the dose reinforce the results obtained from the interaction; higher values for $\mathrm{CD}, \mathrm{RDM}$, TDM and DQI were obtained with the use of $2 \mathrm{~g} \mathrm{~L}^{-1}$, showing that the highest dose under test $\left(3 \mathrm{~g} \mathrm{~L}^{-1}\right)$ results in constant values for these variables, i.e. an increase in fertiliser dose does not induce any increase in the plant growth variables, and significantly reduces efficiency in the use of this input. Studies like the present work, which consider the species and its peculiarities, allow the rational and efficient use of nutrients by the plant, avoiding waste (Shi et al., 2019) and providing balanced nutrition, with higher values for such variables as collar diameter, and a well-developed root system, characteristics of commercial interest.

The larger amount of root dry matter suggests greater capacity of the seedlings to absorb and transport water and nutrients from the roots to the shoots, as well as to withstand any limitations and adversities they may suffer after planting, making this attribute uniquely important when recommending vigorous seedlings for a wide range of field conditions (Grossnickle \& MacDonald, 2018). A positive relationship between the size of the root system and post-planting seedling growth suggests the possibility of employing these characteristics, that can be measured in the nursery and which had greater values when the dose of $2 \mathrm{~g} \mathrm{~L}^{-1}$ was used during this experiment, as indicators of successful seedling growth in the field (Grossnickle \& MacDonald, 2018, Shi et al., 2019).

The DQI, a more-efficient index for evaluating the quality of the produced seedling, as it combines several biometric plant parameters (Gomes \& Paiva, 2013), also registered its greatest value when the dose of $2 \mathrm{~g} \mathrm{~L}^{-1} \mathrm{CRF}$ was used, reinforcing the possibility of this dose being recommended as the most efficient for the use of fertiliser by the plant, since this treatment induced the highest value for this index, regardless of the light level used during cultivation.

It is worth noting that the lack of fertilisation management, or doses lower than that required by the species, may have limited the expression of maximum plant vigour, since the values for each growth variable was significantly lower in plants submitted to these treatments. These results may be related to the need to provide the substrate, in this case sand, with a minimum amount of nutrients through the use of fertilisers in predetermined doses relevant to the species, since, by itself, sand is an inert material, devoid of the essential nutrients for plant growth and development (Dutra et al., 2016).

If the effects of luminosity is considered separately, the better results for root dry matter, total dry matter and DQI, at the highest level of light intensity may have been the result of a reduction in the water available to the plant roots due to more water evaporating from the substrate through the greater exposure to light, forcing the plant to translocate a larger amount of assimilates to the root system, and resulting in greater root growth for water uptake in deeper regions of the substrate (Arantes et al., 2019).

Studying the species Mimosa caesalpiniifolia Benth. and Sterculia foetida L. (Câmara \& Endres, 2008) concluded that $50 \%$ luminosity afforded the best development during the seedling production phase, underlining that this mean reduction in the effects of direct radiation, reduces damage to juvenile plant tissue, but not to the point of restricting the ideal amount of light required for photosynthetic activity, i.e. the conversion of light energy into chemical energy, indispensable for the metabolic processes of the plant that culminate in growth.

In general, the results of this study suggest that plants of Agonandra brasiliensis grown in a protected environment at the highest level of light intensity (50\%), show better use of productive resources (nutrients, water, temperature, light, etc), and that the use of CRF incorporated into the substrate, together with the environment, promotes better initial growth, allowing seedlings of high vigour to be obtained.

\section{CONCLUSIONS}

Growth in seedlings of Agonandra brasiliensis is influenced by the luminosity levels of the production environment, as well as by the doses of controlled-release fertiliser incorporated into the sand substrate. 
The use of $2 \mathrm{~g} \mathrm{~L}^{-1} \mathrm{CRF}$ and cultivation in a greenhouse under $50 \%$ luminosity is suggested for maximizing the growth of plants of Agonandra brasiliensis and ensuring the best use of this input by the plant.

\section{SUBMISSION STATUS}

Received: 15 Apr. 2020

Accepted: 25 Sep. 2020

Associate editor: Marcos Pereira (D)

\section{CORRESPONDENCE TO Renata Menegatti}

Universidade do Estado de Santa Catarina, Ciências Agrárias, 1200, CEP 88523-000, Lages, SC, Brasil

e-mail: renata.d.menegatti@gmail.com

\section{REFERENCES}

Ao Y, Hirst PM, Li G, Miao Y, Zhang R. Combined effects of provenance and slow-release fertilizer on nursery and field performance of yellowhorn seedlings. Silva Fennica 2018; 52(2): 110-117.

Arantes CR de A, Pallaoro DS, Correa AR, Camili EC, Coelho M de FB. Sombreamento e substrato na produção de mudas de Lactuca canadenses L. Iheringia 2019; 74(1).

Araújo JM de, Andrade Neto R de C, Oliveira JR de, Lunz AMP, Almeida UO de. Shading and slow release fertilizer effects on the growth characteristics of açai seedlings (Euterpe oleracea). Floresta e Ambiente 2019; 26(3): 31-39.

Asante MOO, Ahiakpa JK, Amoatey C, Adjei-Nsiah S. Effect of shade and level of fertilizer application on nutrient uptake and dry matter partitioning in cocoyam (Xanthosoma sagittifolium L.). Journal of plant nutrition 2017; 40(16): 2312-2325.

Azeem B, Kushaari K, Homem ZB, Basit A, Thanh TH. Review on materials \& methods to produce controlled release coated urea fertilizer. Journal of Controlled Release 2014; 181: 11-21.

Câmara CA, Endres L. Desenvolvimento de mudas de duas espécies arbóreas: Mimosa caesalpiniifolia Benth. e Sterculia foetida L. sob diferentes níveis de sombreamento em viveiro. Floresta 2008; 38(1): 43-51.

Confederação Nacional da Indústria (CNI). Florestas plantadas: oportunidades e desafios da indústria de base florestal no caminho da sustentabilidade. National Confederation of the Industry, Brazilian Industry of Trees. Brasília; 2017.

Cysneiros CV, Mendonça Júnior J de O, Tomaz LR, Moraes JCR de, Samor OM. Espécies madeireiras da Amazônia: riqueza, nomes populares e suas peculiaridades. Brazilian Journal of Forest Research 2018; 38: 1-14.

Dutra TR, Massa MD, Sarmento MFQ. Fertilizante de liberação lenta no crescimento e qualidade de mudas de canafístula (Peltophorum dubium). Revista Floresta 2016; 46: 491-498.
Epstein E, Bloom AJ. Mineral nutrition of plants. Sunderland: Sinauer Associates; 2006.

Ferreira DF. Sisvar: a computer statistical analysis system. Ciência Agrotecnologia 2011; 35(6): 1039-1042.

Fu YL, Oliet JÁ, Li GL, Wang JX. 2017. Effect of controlled release fertilizer type and rate on mineral nutrients, non-structural carbohydrates, and field performance of Chinese pine containergrown seedlings. Silva Fennica 2017; 51(2): 1607.

Gomes JM, Paiva HN. 2013. Viveiros florestais: propagação sexuada. Viçosa, Brazil. Universidade Federal de Viçosa; 2013.

Grossnickle SC, MacDonald JE. Why seedlings grow: influence of plant attributes. New ForestS 2018; 49: 1-34.

Gualberto MLC, Ribeiro RB da S, Gama JRV, Vieira D dos S. 2014. Fitossociologia e potencial de espécies arbóreas em ecossistema sucessional na floresta nacional do Tapajós. Agroecossistemas 2014; 20146 (1): 42-57.

Guo J, Wu Y, Wang B, Lu Y, Cao F, Wang G. 2016. The effects of fertilization on the growth and physiological characteristics of Ginkgo biloba L. Forests 2016; 7: 293.

Menegatti RD, Guollo K, Navroski MC, Vargas OF. Fertilizante de liberação lenta no crescimento inicial de Aspidosperma parvifoliumA. DC. Sciencia Agraria Paranaensis 2017; 16(2): 45-49.

Menegatti RD, Bianchi VJ. Características fisiológicas, nutricionais e de crescimento de porta-enxertos de pessegueiro submetidos a diferentes fontes e doses de fertilizantes. Acta Iguazu 2019; 8(4): 64-77.

Moraes KNO, Almeida M de C, Pinheiro RM, Dias MRQ. Avaliação biométrica de sementes de Agonandra brasiliensis Miersex Benth. \& Hook. F. (Opiliaceae). South American Journal of Basic Education, Technical and Technological 2018; 5(1).

Pan S, Liu H, Mo Z, Patterson B, Duan M, Tian HN et al. Effects of nitrogen and shading on root morphologies, nutrient accumulation, and photosynthetic parameters in different rice genotypes. Sci Rep 2016; 6: 32148 .

Ramalho AJ, Zappi DC. Flora of the cangas of Serra dos Carajás, Pará, Brazil: Opiliaceae. Rodriguésia 2017; 68(3): 1059-1061.

Schott KM, Snively AEK, Landhäusser SM, Pinno BD. Nutrient loaded seedlings reduce the need for field fertilization and vegetation management on boreal forest reclamation sites. New Forests 2016; 47: 393-410.

Shi W, Grossnickle SC, Li G, Su S, Liu Y. Fertilization and irrigation regimes influence on seedling attributes and field performance of Pinus tabuliformis Carr. International Journal of Forest Research 2019; 92: 97-107.

Smiderle OJ, Souza A das G, Menegatti RD. Controlled-release fertilizer in the production of seedlings of Anonna cacans Warm. Journal of Agricultural Studies 2020; 8(3): 125-133.

Souza A das G, Smiderle OJ, RA Montenegro, TK Moriyama, TJ Dias. 2020. Controlled-release fertiliser and substrates on seedling growth and quality in Agonandra brasiliensis in Roraima. Journal of Agricultural Studies 2020; 8(3): 70-80.

Wang P, Lombi E, Zhao FJ, Kopittke 2016. Nanotechnology: A New Opportunity in Plant Sciences. Trends Plant Science 2016; 8: 699-712. 